\title{
PSYCHE
}

Vol. 99

1992

No. 4

\section{THE NEARCTIC SPECIES OF ELONUS (COLEOPTERA: ADERIDAE)}

\author{
BY FlOYD G. WERNER* \\ Department of Entomology \\ The University of Arizona \\ Tucson, Arizona 85721
}

\section{INTRODUCTION}

Nearctic and Neotropical Aderidae are generally poorly represented in collections, and have therefore been difficult to study. The author has recently treated the species of eastern North America (Werner 1990), most of them for the first time since Casey's 1895 revision. Additional species have accumulated in collections from the western United States, particularly the Southwest.

Because of the proximity of Mexico, these species must be studied in relation to those described from the Neotropical Region. Comparison with the types of the species described by G. C. Champion (1887) in the Biologia Centrali-Americana is critical. The author had the opportunity to examine these types in 1990 , and the officials of the The Natural History Museum in London have graciously sent the types of the species of Elonus for study. The officials of the Museum National d'Histoire Naturelle in Paris have also sent the Elonus types of Maurice Pic, of species described from Brazil under the generic name Hylophilus, but accorded assignment to Elonus as a subgenus by M. Pic.

A review of Neotropical species will be the subject of a separate paper. This paper covers the fauna of the southwestern U.S.A. and is the first in what is projected to be a short series on this fauna.

Manuscript received 10 August 1992.

* Deceased 20 December 1992. 
The three North American species are included in order to make it more generally useful.

The family is more familiarly known as Euglenidae in North America but this name is a homonym of a family of flagellates, based on the genus Euglena and familiar to a much wider audience. The International Commission on Zoological Nomenclature has recently (Anon. 1989) chosen the family-group name Aderidae, based on Aderus Westwood, over an altered family-group name Euglenesidae, based on Euglenes Westwood. Two other family-group names that have been in use, Xylophilidae and Hylophilidae, are secondary homonyms.

The genus Elonus over most of eastern North America is encountered on the leaves of broad-leaved plants, and usually is taken by beating vegetation. One species, E. hesperus Werner, which occurs in western Missouri, eastern Oklahoma, coastal Texas and southeastern Arizona, comes to light at night and is easily taken in light traps. This is also the case with the Southwestern species that are described here. Males are much more frequent than females at light. Unfortunately, there seems to be no way to distinguish species in the few females that have been taken at light in the Southwest.

\section{Genus Elonus Casey}

Elonus Casey 1895: 774 (type-species Xylophilus nebulosus LeConte, designated by Werner 1990: 228). Baguena 1948: 27. Hylophilus (Elonus): Pic 1905: 235.

Diagnosis: The following diagnosis of the genus is expanded from Werner (1990). Rather large species, with deep, flatbottomed punctures, especially well developed on elytra, moderately long and erect setae, and quite dense interstitial setae, directed laterally on elytra. Eyes deeply emarginate, with erect setae.

Abdomen of unusual conformation. Visible sterna 1 and 2 (true sterna 3 and 4) distinctly separated at the sides, beside the hind coxae, sternum 3 appearing as a small triangle, then fused so thoroughly across the sternum that the appearance is of an Adephaga type of abdomen. There is a lateral zone of appressed golden setae, directed posteriorly, on the sides of true sternum 4 , behind the 
suture with sternum 3 , on the abdomen of both sexes. In males a median plate is demarcated on true sterna $4-6$, weakly on 4 , distinctly on 5 , and as an at least slightly elevated lobe on 6 . The sides of the sterna next to this plate are variably provided with appressed golden setae, plush-like short, appressed pubescence, or both.

Males with antennal segment 11 variably elongate, an apical spine on the front tibia, variable bowing of the tibiae, and enlargement of the second basitarsus, the last with a brush of long erect setae on the anterior side, the posterior side variably flattened and pubescent and often angular at the top corner of the apex. Most species have a broad ventral pad of plush-like "setae" on the hind femur.

Females with a dorsal pencil of golden setae on the apex of the hind tibia and a small, seta-filled pit in the middle of the posterior portion of the last visible sternum.

All of the legs of the male are involved in variability of the secondary sexual modifications.

The spine on the apex of the front tibia is always present, but differs in length and strength. The front tibia is bowed to some extent in all species, but only slightly in some.

The middle legs are more variable. The tibia is almost always bowed, sometimes with a slight angle in the bend. The flexor side always has some modification of the pubescence. The simplest modification is into short, appressed, setae; the most extreme modification is into what are here called "scales." These are so small that they are hard to interpret. In a slide preparation of tibia 2 of $E$. hesperus, the "scales" can be seen to be setae, flattened in the plane of the tibia, broadened from near base and tapering to apex, about 8 times as long as broad, appressed and curved just enough that they lie parallel to the tibia for most of their length, with the tip curved down toward the tibia.

The flexor side itself can be normally convex in cross section, slightly flattened ("semi-flattened") with no sharp boundary to the flattened area, or "flattened," with the surface really flat and demarcated by sharp edges. The species with the middle tibia most modified usually have some modification of the middle femur as well, at least a swelling of the flexor surface toward the end, sometimes with modification of the setae of this region, including the presence of "scales." 
The hind legs are most modified. E. simplex, sp. n., has only a vague zone of slightly finer setae, barely discernible. All other known species have a large pad of modified setae on the ventral surface. The setae are wide at the base, curved, and somewhat spatulate at the apex. See Werner (1990, Figs. 47, 60, 61, 67, 68) for SEM photographs. This pad is variably excavated in the basoposterior portion in all species, in the most extreme case the excavation continuing all of the way across the pad. The excavation sometimes seems to have an accumulation of some pale amorphous substance, a possible indication of associated glands. The tibia may be bowed at the base if the pad is broad, and the tip of the tibia variably provided with a tuft of longer setae. One undescribed Neotropical species has a long terminal tibial spine.

The ventral plate on the abdomen of the male (Werner 1990: Fig. 47 for a SEM photograph) varies mainly in the sharpness of the definition of its sides and in the shape of the elevated posterior lobe. In addition there is variation in the surface and pubescence of both the plate and the rest of the surface of the abdominal sterna.

The leg and abdominal modifications of the male are not matched in the female. The brush at the apex of the hind tibia varies slightly in its development, but not strikingly. The female antenna is stouter and shorter than that of the male, and increases in thickness to segment 11, which is not elongated as it is in the male. Females are very difficult to identify to species unless there is a distinctive color pattern.

\section{Elonus basalis (LeConte)}

(Fig. 1)

Xylophilus basalis LeConte 1855: 276; 1878: 426. Casey 1895: 776 (Elonus). Werner 1990: 228 (Elonus).

Elonus princeps Casey 1895: 775.

Diagnosis. Robust; black with red humeri. Fresh specimens with a narrow border of gray pubescence along the suture and in a very weak postmedian lateral cloud on the elytra, laterally on the pronotum and laterally on the head. Measured specimen $2.93 \mathrm{~mm}$ long, 1.28 wide, elytra $2.30(2.12-2.41)$ long. Separation of eyes $14 \%$, length of antennae $238 \%$ of head width in male, $31 \%$ and $207 \%$ in female. 

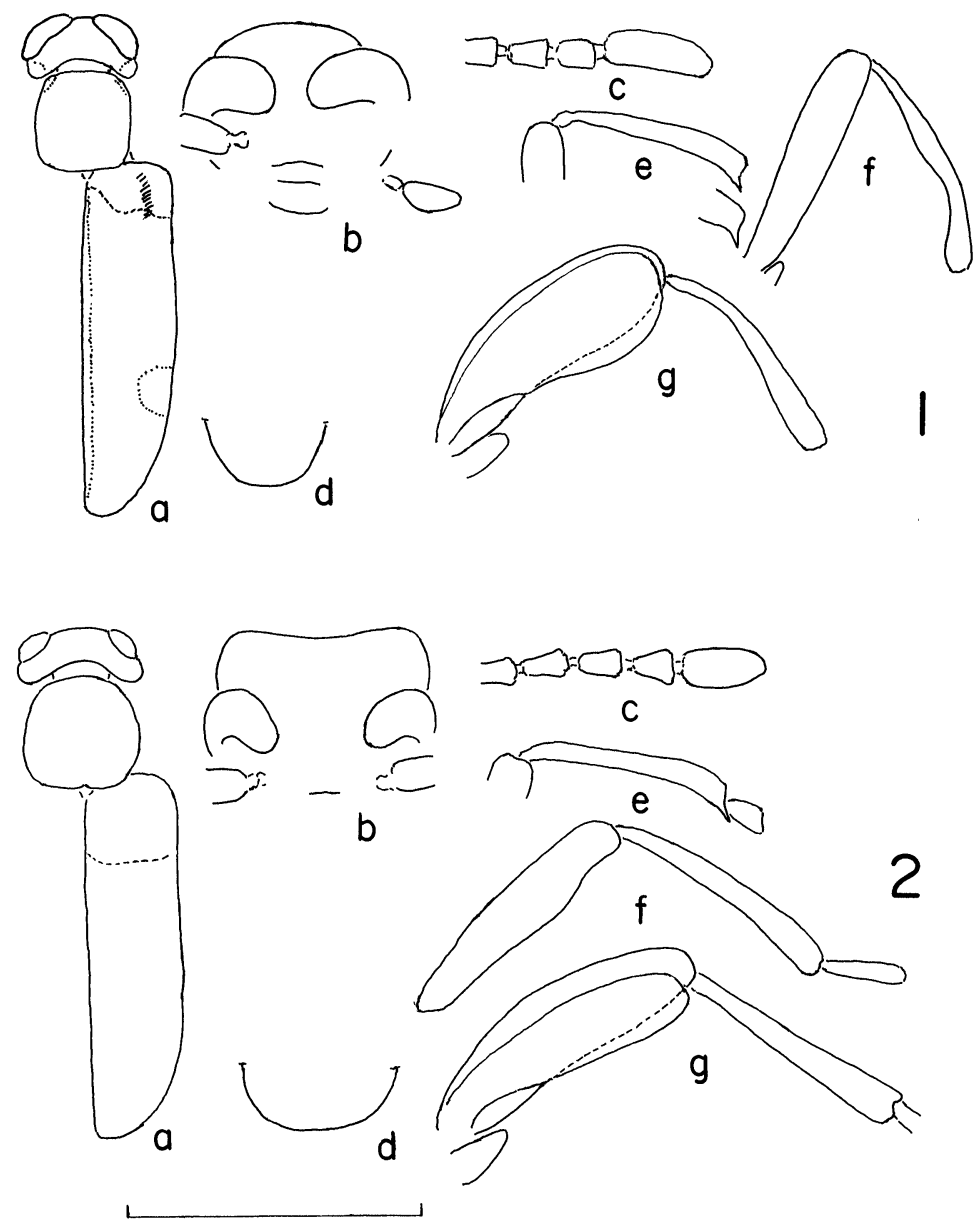

Figs. 1-2. Camera lucida sketches of males of Elonus species. 1, E. basalis (LeConte), Latimer Co., Oklahoma. 2, E. chisosensis, sp. n., holotype. Letters indicate: a, dorsal habitus; b, facial view of head; c, terminal antennal segments; $d$, lobe of abdominal plate on true sternum 6; e, front leg; $\mathrm{f}$, middle leg; $\mathrm{g}$, hind leg. Scale = $2 \mathrm{~mm}$ for a, $1 \mathrm{~mm}$ for $\mathrm{b}-\mathrm{g}$. 
Description. Head broadest just behind eyes, then fairly tightly curved to base, which is gently, evenly concave in facial view. Eyes moderately large, $0.43 \times 0.40 \mathrm{~mm}$ in male, $0.41 \times 0.32$ in female, with moderately short, $0.05 \mathrm{~mm}$, setae. Antennal segment 11 moderately long, $0.35 \times 0.13$ in male, short, $0.25 \times 0.14$ in female.

Femur 1 with moderately dense, $0.05 \mathrm{~mm}$, appressed setae, increasing to $0.06 \mathrm{~mm}$ just before apex, on all surfaces, some setae decumbent in apical zone of flexor side. Tibia 1 gently, evenly bowed, with moderately sparse, $0.08 \mathrm{~mm}$, suberect pubescence on extensor side, denser golden pubescence on flexor side, appressed at base to subdecumbent at apex, extending across anterior side to form a weakly defined brush. Apical spine moderately strong.

Femur 2 not bulging, with moderately sparse simple appressed pubescence over whole surface. Tibia 2 nearly straight, gently curved at apical $2 / 5$. Extensor side with moderately sparse, 0.08 $\mathrm{mm}$, subdecumbent pubescence. Flexor side semi-flattened on curve, with an even coating of short, strongly appressed setae, almost scaly, along whole side, becoming slightly longer and less appressed in apical 1/5. Metatarsus 2 without a spine, its posterior side not flattened or margined, pubescent.

Femur 3 with a moderately dense pad of $0.05 \mathrm{~mm}$ setae, its hind margin not augmented by longer dorsal setae. Basal excavation oblique, $0.08 \mathrm{~mm}$ wide, parallel to side of trochanter, sharply defined, bare on bottom, its anterior edge curving strongly at hind margin, grading to parallel to hind edge, extending almost all of the way to the front edge at the base of the femur. Front edge of excavation with what appear to be much denser short, $0.05 \mathrm{~mm}$, golden setae lining excavation. Hind margin sharp next to trochanter, with some sparse, $0.08 \mathrm{~mm}$, setae. Hind trochanter flattened, nearly glabrous on flat portion. Tibia 3 gently curved, more strongly in basal $1 / 2$, gradually thicker. Extensor side with moderately sparse, $0.08 \mathrm{~mm}$, subdecumbent setae, and more erect, 0.04 $\mathrm{mm}$, undersetae. Flexor side with decumbent $0.05 \mathrm{~mm}$ setae at base, much denser in apical $1 / 2$.

Abdominal sterna with moderately sparse punctures, $0.04 \mathrm{~mm}$ center to center, and appressed setae over whole surface. Lobe of sternal plate almost evenly rounded across apex, its setae continuing to edge to form a fringe $0.07 \mathrm{~mm}$ wide. Surface of disc of lobe slightly flattened and gently concave in apical zone. Last visible 
sternum with apex evenly rounded, transversely gently convex, more strongly at sides, plane longitudinally, its setae $0.07 \mathrm{~mm}$ long, subdecumbent, mostly directed toward midline.

Distribution: Florida to eastern Oklahoma, north to Quebec and Minnesota.

\section{Elonus chisosensis, sp. n.}

(Fig. 2)

Diagnosis. Dark, red across base of elytra, the boundary well defined. Male: antennae unusually slender, segment 11 unusually short. Eyes small. Middle tibiae almost straight. Pad of femur 3 narrow, with a simple excavation at base, parallel to trochanter. Metatarsus 2 without spine and its posterior side not flattened. Separation of eyes $33 \%$, length of antenna $246 \%$ of width of head across eyes in male (female unknown). Length $3.77 \mathrm{~mm}$, width 1.27 , elytra $2.72(2.10-2.72) \mathrm{mm}$ long.

Description. Holotype, male: $3.77 \mathrm{~mm}$ long with head deflexed. Head $0.52 \mathrm{~mm}$ long to frontoclypeal suture, 0.85 wide across eyes, 0.87 behind, the base $0.14 \mathrm{~mm}$ long behind eyes, the sides slightly convex and widest behind eyes, evenly curved from eyes to truncate base, which is concave by $0.02 \mathrm{~mm}$ in facial view. Eyes not very prominent, $0.40 \times 0.27 \mathrm{~mm}$, separated by 0.27 , with erect setae moderately long, $0.08 \mathrm{~mm}$. Antenna $2.03 \mathrm{~mm}$ long, segment 11 unusually short, $0.30 \times 0.13 \mathrm{~mm}$. Prothorax $0.81 \mathrm{~mm}$ long, 0.79 wide, its base with a small median notch. Elytra $2.72 \mathrm{~mm}$ long, 1.16 wide at points of humeri, 1.27 maximum.

Femur 1 simple. Tibia $10.70 \mathrm{~mm}$ long, nearly straight, bowed by $0.03 \mathrm{~mm}$, mainly in apical third, with a moderately long, 0.10 $\mathrm{mm}$, and slender apical spine. Extensor side with moderately long, $0.11 \mathrm{~mm}$, decumbent setae; flexor side with setae similar but more appressed.

Femur 2 simple with a slight expansion beyond middle of flexor side, with $0.10 \mathrm{~mm}$ setae, appressed on flexor, decumbent on extensor side. Tibia 2 almost straight, bowed by $0.03 \mathrm{~mm}$, slightly the more strongly beyond middle. Setae similar to femur 2, subdecumbent on extensor, short and appressed on flexor side. Basitarsus 2 with apex simple and posterior side not flattened, bearing some setae. 
Femur $31.10 \mathrm{~mm}$ long, 0.25 wide without pad, which is made up of setae about $0.10 \mathrm{~mm}$ long and dense enough to obscure surface quite well. Pad moderately narrow and of nearly uniform width; basal excavation simple, parallel to trochanter. Posterior edge of pad bordered above with some sparse regular setae. The excavation appears to have no cuticular boundary with the pad; it looks like a zone without setae, defined by simple setae directed obliquely backward from front and along margin behind. Setae of extensor side of femur subdecumbent, $0.10 \mathrm{~mm}$, shaggy. Tibia 3 straight, with setae similar to femur on extensor side, more erect toward apex, and slightly shorter and more decumbent setae on flexor side.

Abdominal plate unusually poorly defined, noticeable mostly because of the golden setae and white pad along its sides, its disc shiny, moderately sparsely punctured and appressed-pubescent, the setae $0.08 \mathrm{~mm}$, overlapping edges. Apical lobe barely elevated above surface of sternum, its apex slightly truncate. Sternum behind lobe gently, evenly convex from side to side, with some suberect setae directed medially.

Distribution: Known only from the Chisos Mountains.

TYPE MATERIAL: Holotype, male, labeled [Big Bend N.P., TEX/HQ-5260'/VII-9-1948 lt./F.Werner] [HOLOTYPE/Elonus/ chisosensis/Werner] in M.C.Z. Paratypes: TEXAS: Brewster Co.: Big Bend National Park, same data as holotype (1); Chisos Basin May 1, 1959 Howden and Becker, at light (2); same but May 29, 1959 (1). Paratypes in BMNH, CNCI, UAIC.

Elonus excavatus Werner, sp. $\mathrm{n}$.

(Fig. 3)

Diagnosis: Dark, red across base of elytra; pubescence not contrasting with cuticle. Dorsally, forebody slightly shiny, elytra shinier. Male: pad of femur 3 with a deep, transverse basal pit. Antennae moderately slender. Separation of eyes $15 \%$, length of antennae $250 \%$ of head width in male (female unknown). Length 2.59 , width $1.20 \mathrm{~mm}$, elytra $2.04(1.85-2.04) \mathrm{mm}$ long.

Description: Holotype, male: $2.59 \mathrm{~mm}$ long with head deflexed. Head in facial view very short, $0.46 \mathrm{~mm}$ long to frontoclypeal suture, 0.63 wide across eyes, widest, 0.57 , just behind, $0.11 \mathrm{~mm}$ long behind eyes. Base almost evenly rounded from eye to eye, 



Figs. 3-6. Camera lucida sketches of males of Elonus species. 3, E. excavatus, sp. n., holotype. 4, E. hesperus Werner, Latimer Co., Oklahoma. 5, E. hesperus, Santa Engracia, Tamaulipas, Mexico. 6, E. hesperus, Molino Basin, Sta. Catalina Mts., Arizona. Explanation of letters and scale as on Figs. 1-2. 
just slightly truncate. Eyes $0.39 \times 0.28 \mathrm{~mm}$, separated by 0.09 , with short, $0.04 \mathrm{~mm}$, setae; upper lobe relatively narrow. Antenna $1.57 \mathrm{~mm}$ long, segment $110.32 \times 0.12 \mathrm{~mm}$.

Prothorax $0.63 \mathrm{~mm}$ long, 0.61 wide; elytra $2.04 \mathrm{~mm}$ long, 0.98 wide at points of humeri, 1.20 maximum. Femur 1 simple. Tibia 1 $0.56 \mathrm{~mm}$ long, nearly straight, bowed by $0.02 \mathrm{~mm}$, with a short, stout apical spine. Femur 2 simple, basal $1 / 3$ of flexor side with dense, short, $0.04 \mathrm{~mm}$, appressed setae, apical $2 / 3$ with some sparse, $0.06 \mathrm{~mm}$, setae. Tibia $20.67 \mathrm{~mm}$ long, gently bowed, by $0.04 \mathrm{~mm}$, with a slight flattening of flexor side and angularity almost at middle between base and apex. Setae of flexor side short and appressed, $0.03 \mathrm{~mm}$, not as short or as dense as on base of flexor side of femur 2. Metatarsus 2 not modified except for anterior brush, its posterior side rounded, not margined, and pubescent.

Femur 3, $0.83 \mathrm{~mm}$ long, 0.22 wide, with an extensive pad (of ca. $0.10 \mathrm{~mm}$ setae) that is margined above by a posterior fringe of setae. Surface visible through setae. Basal excavation extending across width of pad and separated from main portion by a nearly transverse ridge in the cuticle, with moderately sparse, suberect curved setae rising to level of surface of pad, and denser, appressed, long, ca. $0.08 \mathrm{~mm}$, golden setae in bottom of excavation. Trochanter 3 with long setae. Tibia 3 almost evenly, gently curved, slightly thicker toward apex. Flexor side with moderately dense $0.05 \mathrm{~mm}$ setae, decumbent but becoming suberect to erect in apical 1/5, $0.06 \mathrm{~mm}$ long, forming a sort of brush there.

Abdominal plate shiny, moderately densely, finely punctured and appressed short-pubescent, with some longer, $0.08 \mathrm{~mm}$, setae overlapping borders. Lobe with apex shallowly concave-truncate, its disc gently concave in apical portion. Rest of sterna shinier and less densely punctured and pubescent than plate. Last visible sternum gently convex from side to side, with some long, $0.08 \mathrm{~mm}$, suberect setae directed medially. Felt conspicuous beside plate on true sterna 5 and 6 , but appressed golden setae sparse and inconspicuous.

Distribution: Known only from southeastern Arizona.

TYPE MATERIAL: Holotype, male, labeled [4 mi. N. Whiteriver/ARIZ. beating/VII-20/22-1948/F. Werner \& W.Nutting] [HOLOTYPE/Elonus/excavatus/Werner], in M.C.Z. Paratypes: 41 males: ARIZONA: Apache Co.: McNary, 4 mi. N., 7400' (1); 
Whiteriver, 4 mi. N., same data as holotype (3). Cochise Co.: Chiricahua Mts.: 7-3-47 (6); Pinery Cn., 7-30-57 (1); Southwestern Research Station, 7-3-67 (1), 5700', 8-5-68 (1), 8-11-57 (1). Gila Co.: Sierra Ancha Mts.: Sept. (4); Workman Creek, 5000', UV light, 7-9-64 (7). Greenlee Co.: Clifton, $21 \mathrm{mi}$. N., 7-12-68 (6). Pima Co.: Sta. Catalina Mts.: Bear Cn., 7-6-69 (6); Bear Cn., Hk. Hwy. Mi. 12, UV trap, 7-9-59 (1), 7-14-61 (1); Upper Bear Cn., 724-65. Pinal Co.: Sta. Catalina Mts., Peppersauce Cn., 4500', 7-2548. Paratypes in BMNH, CDAE, CNCI, DENH, FSCA, MCZ, MNHN, SEMC, UAIC.

\section{Elonus hesperus Werner}

(Fig. 4)

Elonus hesperus Werner 1990: 229.

Diagnosis: Robust, dark with base of elytra red; interstitial pubescence evenly gray. Middle femur bulged in apical third of flexor side. Metatarsus 2 with apex angular. Femur 3 with a double excavation at the base. Holotype $2.71 \mathrm{~mm}$ long with head deflexed, 0.98 wide, elytra $1.91(1.90-2.12) \mathrm{mm}$ long. Separation of eyes $28 \%$, length of antennae $208 \%$ of head width in male, $34 \%$ and $197 \%$ in female.

Description, male: eyes moderately large and prominent, $0.38 \times$ $0.30 \mathrm{~mm}(0.37 \times 0.27$ in female), with moderately long, $0.06 \mathrm{~mm}$ setae. Base of head in facial view with sides nearly parallel, just barely concave behind eyes for a short distance, then strongly curved to base that is evenly concave by $0.03 \mathrm{~mm}$. Antennal segment 11 moderately long, $0.37 \times 0.13 \mathrm{~mm}$ (short, $0.26 \times 0.15$ in female).

Flexor side of femur 1 with moderately sparse, normally long, $0.06 \mathrm{~mm}$, subdecumbent setae, denser but still not very dense in basal $1 / 4$. Tibia 1 gently bowed with a slight accentuation midway between base and apex, with moderately dense setae $0.06-0.08 \mathrm{~mm}$ long, appressed in basal $1 / 2$, to subdecumbent in apical $1 / 3$, where they appear as a sort of weak brush. Apical spine moderately strong.

Femur 2 bulged at apical $1 / 3$ of flexor side, extensor side with only appressed setae, short, $0.05 \mathrm{~mm}$, with sparse longer, $0.08 \mathrm{~mm}$, 
setae toward apex. Flexor surface, including trochanter, scaly to bulge, gradually changing to short appressed-pubescent. Tibiae 2 and 3 with moderately dense, long, $0.10 \mathrm{~mm}$, subdecumbent setae on extensor side. Tibia 2 gently bowed with a slight accentuation just beyond middle, slightly flattened from base to there; apical zone not flattened. Whole flexor side scaly, without sign of normal setae toward apex. Metatarsus 2 with a 30 degree sharp angle at apex, its posterior side flattened but not margined, shortpubescent.

Femur 3 with a moderately dense pad that somewhat conceals the surface. Pad setae short, $0.05 \mathrm{~mm}$, forming the only fringe at the back edge, with no setae above them. Basal excavation very slightly less densely pubescent, the ridge demarcating it from the rest of the pad almost semicircularly curved from hind margin to paralleling and close to front margin anteriorly. A second, narrow, excavation, separated from the other by a low ridge, is parallel to the margin of femur and trochanter and of about the same length as the trochanter; it appears to be more glabrous. The sharply defined edge by the trochanter has a zone of thicker decumbent setae 0.13 $\mathrm{mm}$ long, these longer and more noticeable beyond trochanter. Tibia 3 gently curved, more strongly in basal $1 / 2$, with normal decumbent setae on flexor side, denser and longer, $0.08 \mathrm{~mm}$, erect and forming a weak brush in apical 1/6.

Abdominal plate shiny, finely and fairly densely punctulate and short appressed-pubescent, with some deeper punctures basally on individual segments. Apex of plate slightly ogival, its disc slightly depressed medio-apically, fringed with moderately dense, 0.08 $\mathrm{mm}$, setae. Last visible sternum with side and apical margins more convex than rest of surface, which is flat or very slightly concave, with decumbent setae $0.10 \mathrm{~mm}$ long, pointing along border on edges, medially over much of disc, erect and curving slightly forward in apical area. Punctures and setae sparser than on plate.

Distribution: Southeastern Oklahoma and western Missouri.

Associated with this species are two populations that might be considered as species if it were not for the fact that they appear to be sister taxa of hesperus and completely allopatric. They differ in the size of the eyes of the male, and, to a lesser degree, in the extent of the bulging of the male middle femora. 
Coastal Texas to Honduras population

(Fig. 5)

Second basitarsus flattened, not margined, densely covered with fine, short pubescence, its apical angle not as sharp as in eastern population. Separation of eyes $14.6 \%$ to $18.4 \%$ of head width in coastal Texas males, $10.0-17.4 \%$ in males from Mexico, 10-14 in males from Honduras. Only 10 specimens seen from Mexico, 2 from Honduras.

Nearctic records. Texas: San Patricio Co.: L. Corpus Christi, 812-76, UV trap (1); Willacy Co.: Raymondville, $11 \mathrm{mi}$. E., 5-4-89 (1); Cameron Co.: Brownsville, 6-29-35 (1). Specimens in CDAE, DENH, SEMC.

\section{Arizona and northwestern Mexico population}

(Fig. 6)

Second basitarsus flattened, even slightly concave on extensor side, which is margined, shiny and short-pubescent. Apical angle not as sharp as in eastern population. Separation of eyes $22 \%$ in male. The single specimen from Sinaloa has the separation $19.6 \%$. The eye size of the Sinaloa specimen is quite different from one associated with the other subgroup, from Acaponeta, Nayarit, which has the percentage 12.8 .

Records. ARIZONA: Greenlee Co.: Clifton, $21 \mathrm{mi}$. N., 7-22-68. Pina Co.: Sta. Catalina Mts.: Sabino Cn., 7-26-48, at light; Molino Basin, 7-14-55, at light. Yavapai Co.: Cherry, light trap. Specimens in CNCI, UAIC.

\section{Elonus nebulosus (LeConte)}

(Fig. 7)

Xylophilus nebulosus LeConte 1875:175. Casey 1895:776 (Elonus). Werner 1990: 230 (Elonus).

Diagnosis: Unique in the Nearctic fauna in its pattern of markings from base to apex of elytra, in both cuticle and pubescence. Hind femur of male with a deep excavation in the base of the pad, and middle tibia terminating in a projection under the basitarsus. 

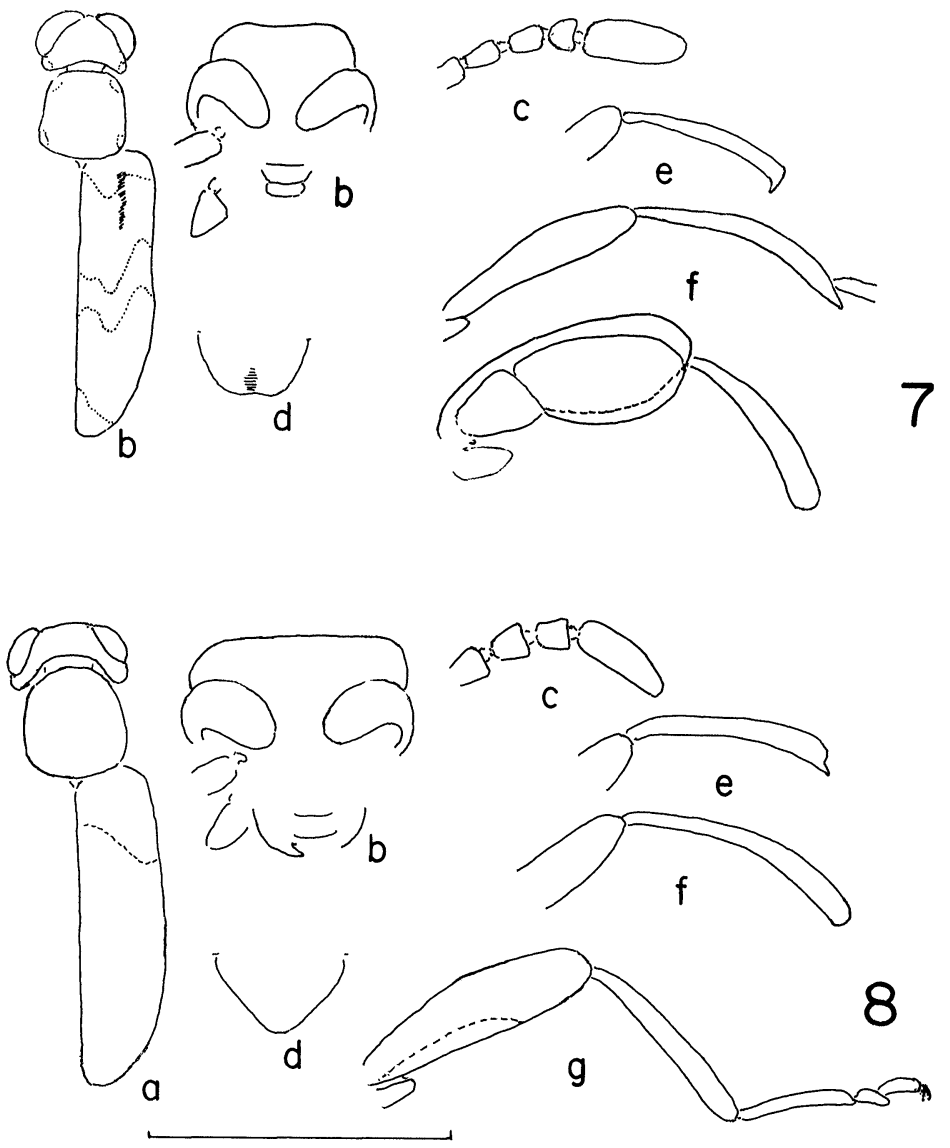

Figs. 7-8. Camera lucida sketches of males of Elonus species. 7, E. nebulosus (LeConte), Latimer Co., Oklahoma. 8, E. simplex, sp. n., holotype. Explanation of letters and scale as on Figs. 1-2.

Measured specimen $2.45 \mathrm{~mm}$ long, 1.02 wide, elytra 1.94 (1.65-2.01 mm long. Separation of eyes $14 \%$, length of antennae $2.86 \%$ of head width in male, $34 \%$ and $223 \%$ in female.

Description, male: eyes moderately large, $0.38 \times 0.32 \mathrm{~mm}(0.36$ $\times 0.29$ in female), with short, $0.05 \mathrm{~mm}$, erect setae. Base widest 
just behind eyes, then evenly curved to truncate apex. Antennal segment 11 moderately long, $0.36 \times 0.13 \mathrm{~mm}(0.24 \times 0.16$ in female).

Femur 1 with short, appressed setae on extensor, slightly longer, $0.08 \mathrm{~mm}$, decumbent setae on flexor side. Tibia 1 gently curved in apical area, with subdecumbent setae similar to femur on both sides, sparse at base, denser toward apex; apical spine moderately strong.

Femur 2 with setae similar to femur 1 . Tibia 1 gently bowed, more strongly at middle longitudinally, with short, $0.02 \mathrm{~mm}$, appressed setae before middle of flexor side, denser, longer, 0.03 $\mathrm{mm}$, beyond middle. Extensor side with subdecumbent setae 0.06 $\mathrm{mm}$ long. Apex projecting to a point below basitarsus. Basitarsus 2 not pointed at apex, its posterior side slightly convex, the borders not sharp, and with some fine punctures and pubescence.

Femur 3 with a moderately dense pad of ca. $0.06 \mathrm{~mm}$ setae, not augmented at hind edge. Basal excavation large, a strong ridge separating it from the rest of the pad, this nearly transverse, sharply curving to a well-defined border in front, and into hind margin behind. Setae of excavation reaching nearly to plane of pad but much sparser, those along hind margin curving forward, most arising from front of cavity. Trochanter with moderately sparse, $0.08-0.11 \mathrm{~mm}$, setae. Tibia 3 gently curved, more strongly in basal $1 / 2$. Extensor side with setae like tibia 2 but slightly longer, 0.05 $\mathrm{mm}$. Flexor side with appressed, $0.05 \mathrm{~mm}$, setae, sparse at base, denser toward apex, the apex itself with a poorly defined brush of denser, $0.06 \mathrm{~mm}$, setae, concentrated on flexor side.

Abdominal plate with moderately dense, $0.03 \mathrm{~mm}$ center to center, and deep punctures, and short, $0.04 \mathrm{~mm}$, appressed pubescence, with some longer, $0.06 \mathrm{~mm}$, less appressed setae; apex of lobe more finely punctured, its disc slightly concave in subapical area and the apex itself almost evenly rounded. Plate with fringe of long, $0.08 \mathrm{~mm}$, setae, parallel to surface of sternum next to plate. Sterna beside plate contrastingly shiny, with longitudinal, 0.08 $\mathrm{mm}$, golden setae, dense on true sterna 4 and 5 , only a few on 6 . Edge of last visible sternum evenly rounded, its surface slightly depressed next to lobe of plate, gently curved to sides in cross section. There is a zone of long, $0.08 \mathrm{~mm}$, setae across its apex, converging toward apex of lobe. 
Distribution: Florida to eastern Oklahoma, north to Quebec and Michigan.

\section{Elonus simplex Werner, sp. $\mathrm{n}$.}

(Fig. 8)

Diagnosis. Dark, red across base of elytra. Male with hind femur simple, a small spine at tip of tibia 1 , slightly curved tibia 2 , and simple tibia 3. Metatarsus 2 with apical spine. Separation of eyes $25 \%$, length of antennae $214 \%$ of head width in male (female unknown). Length 2.85, width $1.19 \mathrm{~mm}$, elytra 2.20 (1.98-2.28) mm long.

Description. Holotype, male: $2.85 \mathrm{~mm}$ long with head deflexed. Head $0.57 \mathrm{~mm}$ long to frontoclypeal suture, 0.81 wide across eyes, 0.80 behind, base $0.13 \mathrm{~mm}$ long behind eyes, curving evenly from margin of eye to base, which is very gently concave. Eyes moderately prominent, $0.43 \times 0.39 \mathrm{~mm}$, separated by 0.20 ; erect setae moderately long, $0.06 \mathrm{~mm}$. Antenna $1.74 \mathrm{~mm}$ long, segment 11 moderate, $0.35 \times 0.11$. Prothorax $0.78 \mathrm{~mm}$ long, 0.72 wide, elytra $2.20 \mathrm{~mm}$ long, 1.11 wide at points of humeri, 1.19 maximum.

Extensor side of femur 1 with moderately short appressed setae, longer, $0.05 \mathrm{~mm}$, and subdecumbent on flexor side. Tibia 10.69 $\mathrm{mm}$ long, gently bowed, by $0.04 \mathrm{~mm}$, slightly more strongly in apical $1 / 3$, with sparse decumbent setae on basal $2 / 3$ of flexor side, then denser and subdecumbent, $0.05 \mathrm{~mm}$, in apical third, around a strong, slightly curved apical spine.

Femur 2 thicker than femur 1 but not modified. Flexor side with fairly sparse short, appressed setae, plus a few longer, $0.05 \mathrm{~mm}$, decumbent setae in apical 1/5. Extensor setae normal, $0.05 \mathrm{~mm}$, appressed. Tibia $20.91 \mathrm{~mm}$ long, gently, almost evenly curved, by $0.02 \mathrm{~mm}$, slightly more strongly in apical $2 / 5$, with even, short, strongly appressed setae (perhaps transitional to "scaly," more clearly setae in basal 1/3) on whole flexor side. Extensor side with much longer, $0.10 \mathrm{~mm}$, moderately dense, subdecumbent setae, shorter in basal 1/3. Metatarsus 2 with a $<30$ degree sharp point, its posterior side flattened and margined, shiny, with only a few long setae.

Femur $30.94 \mathrm{~mm}$ long, 0.24 wide, without a pad but posterior half of basal 2/3 of ventral (anatomically anterior) side with a zone 
of slightly denser, very fine, suberect setae on a paler cuticle that may be the equivalent. Rest of ventral and flexor sides also with short, appressed setae, except several longer, $0.08 \mathrm{~mm}$, setae in apical area. Extensor side with setae short and decumbent at base, grading to moderately dense, $0.06 \mathrm{~mm}$, and subdecumbent at apical $1 / 3$, gradually shorter to apex. Trochanter 3 not flat and with no long setae. Tibia 3 nearly straight. Setae of extensor side moderately dense, subdecumbent, $0.11 \mathrm{~mm}$, shorter in basal $1 / 4$. Setae of flexor side short and decumbent in basal $1 / 2$, to longer, $0.10 \mathrm{~mm}$, and subdecumbent in apical $1 / 3$.

Abdominal plate slightly more weakly defined than in most species with padded femur 3 , its surface shiny. Whole surface of lobe with moderately dense normal punctures and decumbent, 0.08 $\mathrm{mm}$, setae, these continuing as a marginal fringe. Last sternum with punctures similar to lobe of plate, slightly sparser. Surface almost evenly, gently convex, more strongly along lateral margins, its setae $0.11 \mathrm{~mm}$ long, decumbent, directed medially on disc, posteriorly on sides.

Distribution: Southeastern Arizona to southern New Mexico and southern Sonora, Mexico.

TYPE MATERIAL: Holotype, male, [Cochise Stronghold, Dragoon Mts.,/ARIZ July 24-27,/1970 RJShaw/U.V.trap] [HOLOTYPE/Elonus/simplex/Werner], in M.C.Z. Paratypes (92); ARIZONA: Cochise Co.: same data as holotype but 6-29/7-2 (1), 7-2/5 (1), 7-8/10 (2), 7-10/12 (1), 7-21/24 (7), 7-24/27 (4), 7-27/30 (6), 8-3/6 (2), 8-16/22 (1); Dragoon Mts., Cochise Stronghold, 728-64, UV 1t. (2); West Stronghold, 7-20-75 (2). Gila Co.: Globe, 7-24-35 (1), 8-18-35 (1), 8-28-52 (1). Pinal Mts.: 6-Shooter Cn., 78-49 at 1t. (4). Pima Co.: Arivaca, 7-26-41 (2). Baboquivari Mts.: 7-18-32 (3); Baboquivari Cn., 8-17-49, at lt. (2); Brown Cn., 7-1849 (4), 8-4-61 UV 1t., 8-4-62, UV trap; Chutum Vaya Cn., 3250', 8-4-66, UV trap (8); Sycamore Cn., on W. slope, 7-27-59 (1). Continental, 10 mi. E., 7-18-61, UV trap (7). Sta. Catalina Mts.: Sabino Cn., 7-25-58 (1), 8-6-48 1t. (1). Sta. Rita Mts.: 7-19-38 (1); Greaterville, 8-5-78 (1); Sta. Rita Range Reserve: IBP site, 712/15-73, UV trap (1), 7-20/22-73 (1). Tucson, 7-30-68 (1). Vail, 8 mi. N., 8-7-66, UV trap (1). Pinal Co.: Sta. Catalina Mts.: Peppersauce Cn., 7-23-58 (1). Sta. Cruz Co.: Atascosa Mts.: Bear Valley, 4000', 7-24-59 (1); Ruby, 7-24-41 (1); Sycamore Cn., 7-20-49. 
Canelo Hills: Canelo, 7-10-57 (1), 7-31-56 (1). Pajarito Mts.: Calabasas Cn., 7-28-48, 1t. (6); Peña Blanca, 7-10-61, UV trap (2), 711-70 (1), 7-28-62 (2). Patagonia, 2 mi. SW, 7-30-48, lt. (1). Patagonia Mts., W. slope, 4400', 7-27/29-48 (3). NEW MEXICO: Grant Co.: Lordsburg, 19 mi. E., 7-15-48 (1). MEXICO: SONORA: Navajoa, $10 \mathrm{mi}$. E., 7-13-59, UV trap (2). Paratypes in BMNH, CDAE, CNCI DENH, EGRC, FSCA, MCZ, MNHN, SEMC, UAIC.

\section{Key to NeARCTIC SPECIES}

1. Elytra with a pattern of pale zig-zag markings medially, in both cuticle and pubescence. Eastern nebulosus

1' Elytra without a pale pattern medially, but with variable development of red humeri, sometimes whole surface reddish

2(1') Elytra with suture narrowly margined with gray pubescence, as well as a lateral postmedian cloud in very fresh specimens. Humeral red area sharply defined. Eastern.... basalis

2' Elytral pubescence not contrasting with color of cuticle, or entirely gray. Western Missouri to southern Arizona ...............3

3(2') Abdomen with a differentiated median plate. Males ...............4

3' Abdomen without a median plate. Last visible sternum with a postmedian central pit. Females, impossible to identify to species without unique association with males.

4(3)Hind femora without a ventral brush. Southeastern Arizona to southern New Mexico and southern Sonora, Mexico. simplex

4' Hind femora with a large ventral brush over most of their surface .5

5(4') Femoral brush with a deep basal excavation that extends almost all of the way across the surface. Southeastern Arizona. 
5' Basal excavation of femoral brush not extending across whole

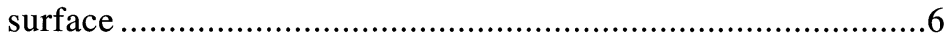

6(5') Basal excavation of femoral brush divided into 2 parts. Western Missouri and eastern Oklahoma, with 2 other distinguishable populations, one from coastal Texas through Mexico to Honduras, the other from southeastern Arizona to Sinaloa, Mexico. hesperus

6' Basal excavation of femoral brush simple, longitudinal, weakly defined. Chisos Mts., Texas. chisosensis

\section{SUMMARY}

Six Nearctic species are described and keyed, three of them new: Elonus chisosensis (Chisos Mts., Texas), E. excavatus (southeastern Arizona), and E. simplex (southeastern Arizona, southern New Mexico and southern Sonora, Mexico). Two allopatric populations assigned to Elonus hesperus Werner are discussed.

\section{ACKNOWLEDGEMENTS}

This paper is dedicated to Professor Frank M. Carpenter in the year of his 90th birthday. His gentle tolerance and encouragement made three years of graduate study a pleasant and memorable experience. I am very much indebted to the following for the loan of specimens and other favors: (BMNH) Darryl Kempster, The Natural History Museum, London, England; (CDAE) Fred Andrews, California Department of Agriculture, Sacramento; (CNCI) Milton Campbell, Canadian National Collection of Insects, Ottawa; (DENH) Don Chandler, University of New Hampshire, Durham; (EGRC) Ed Riley, College Station, Texas; (FSCA) Mike Thomas, Florida State Collection of Arthropods, Gainesville; (MCZ) Dave Furth, Museum of Comparative Zoology, Harvard University, Cambridge, Massachusetts; (MNHN) Nicole Berti, Museum National d'Histoire Naturelle, Paris, France; (SEMC) Jim Pakaluk, University of Kansas, Lawrence; (UAIC) Carl Olson, University of Arizona, Tucson. 


\section{REFERENCES}

ANONYMOUS

1989. Opinion 1549. Euglenidae Stein 1878 (Protista, Flagellata) and Euglenidae Seidlitz 1875 (Insecta, Coleoptera) homonymy removed, and Aderidae Winkler 1927 (Insecta, Coleoptera) given precedence over Euglenesidae Seidlitz 1875. Bulletin of Zoological Nomenclature 46(3): 193-194.

Baguena CoRella, L.

1948. Estudio sobre los Aderidae. Instituto de Estudios Africanos, Madrid. $547 \mathrm{pp}$.

CASEY, T. L.

1895. Coleopterological notices. VI. Annals of the New York Academy of Sciences 8: $435-838$.

Champion, G. C.

1890. Biologia Centrali-Americana. Insecta, Coleoptera, Xylophilidae 4(2): 166-190, pl. 8.

LECONTE, J. L.

1855. Synopsis of the Pyrochroides of the United States. Proceedings of the Academy of Natural Sciences of Philadelphia 7: 270-277.

1875. Descriptions of new Coleoptera of the United States with notes on geographical distribution. Transactions of the American Entomological Society 5: 169-176.

1878. Additional descriptions of new species, pp 373-434. In E. A. Schwarz, The Coleoptera of Florida. Proceedings of the American Philosophical Society 17: 353-472.

PIC, M.

1905. Contribution a l'etude generale des Hylophilidae. Annales de la Societe entomologique de France 74: 181-286.

WERNER, F. G.

1990. Revision of the Aderidae of eastern North America. Journal of the New York Entomological Society 98(2): 187-232. 

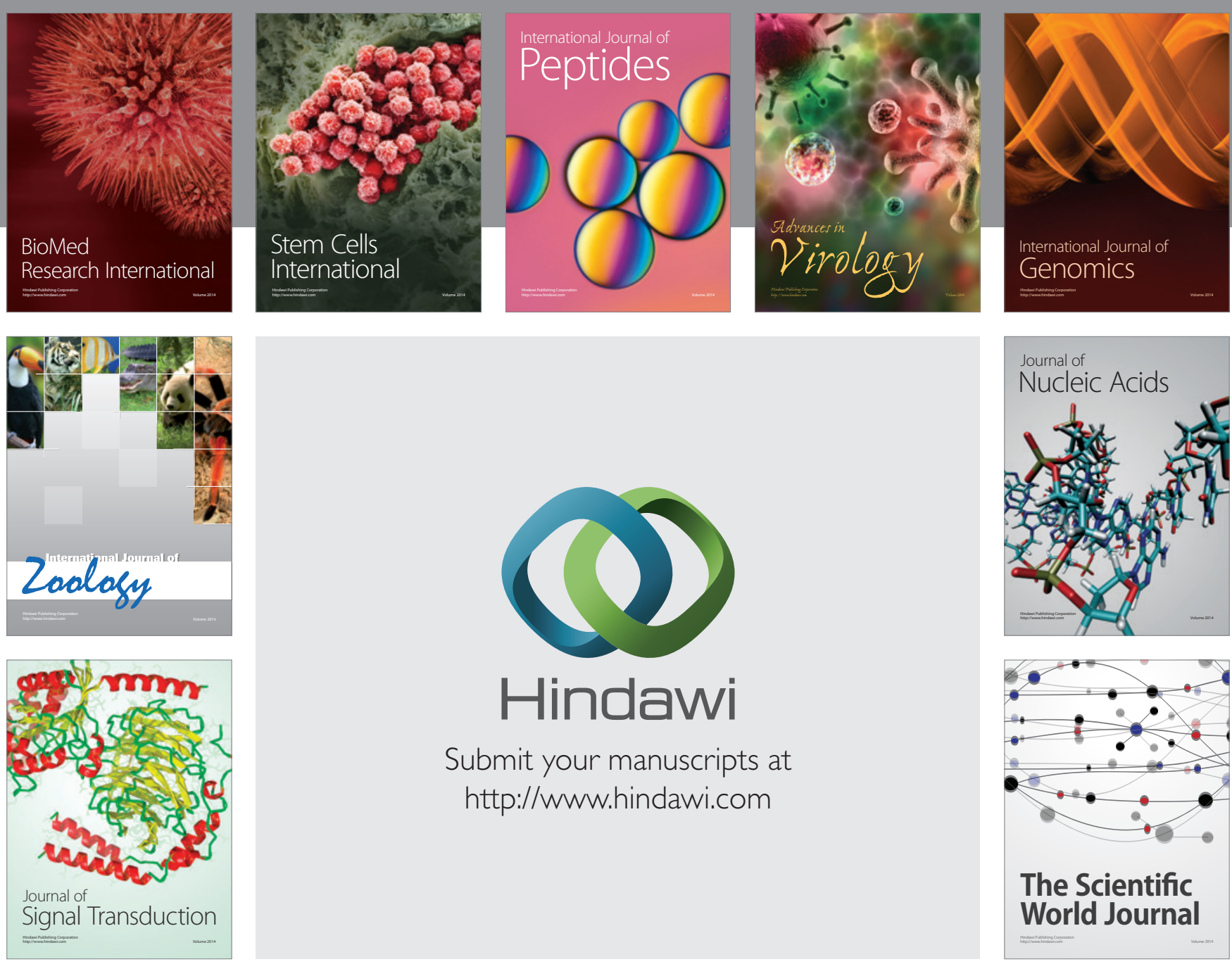

Submit your manuscripts at

http://www.hindawi.com
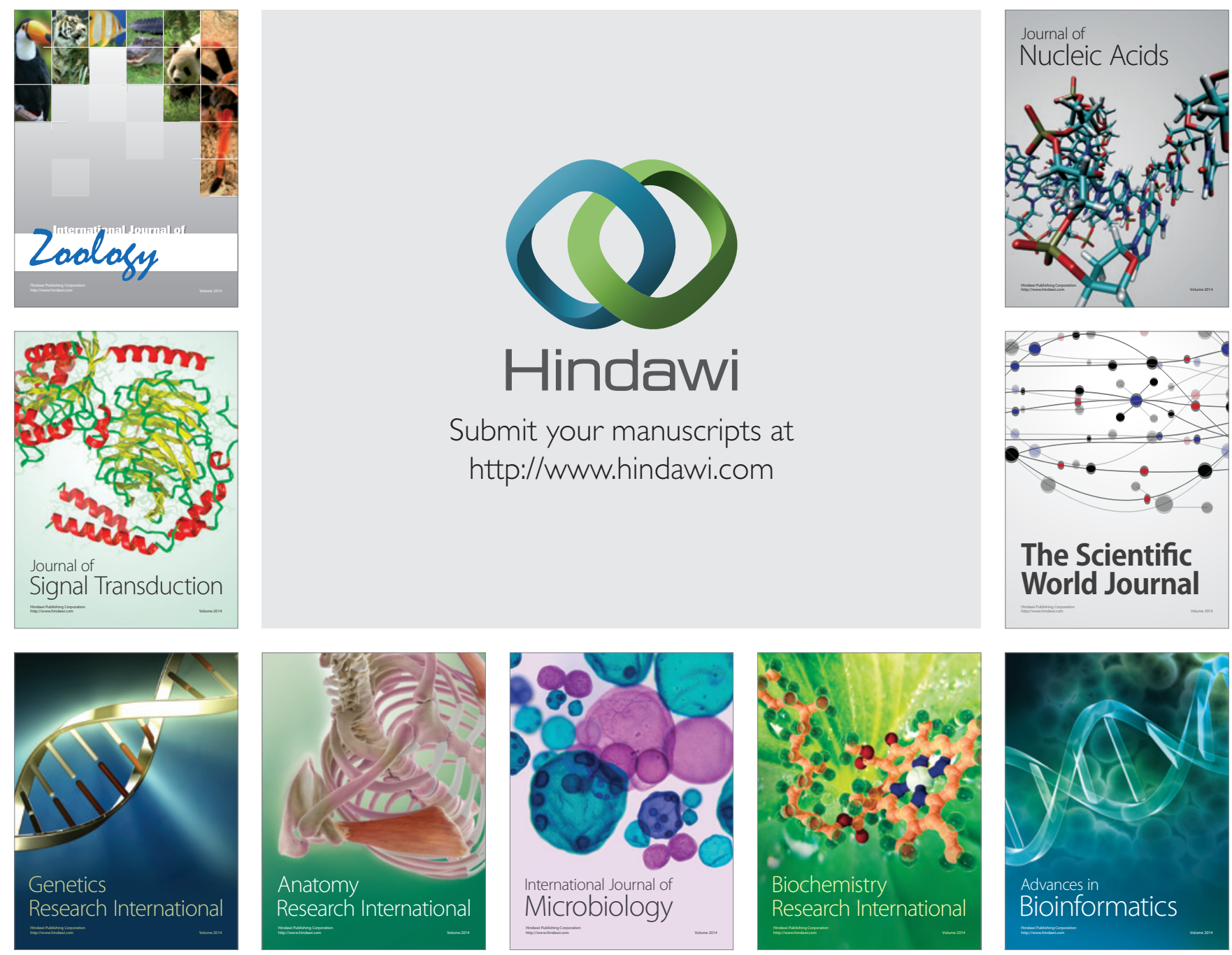

The Scientific World Journal
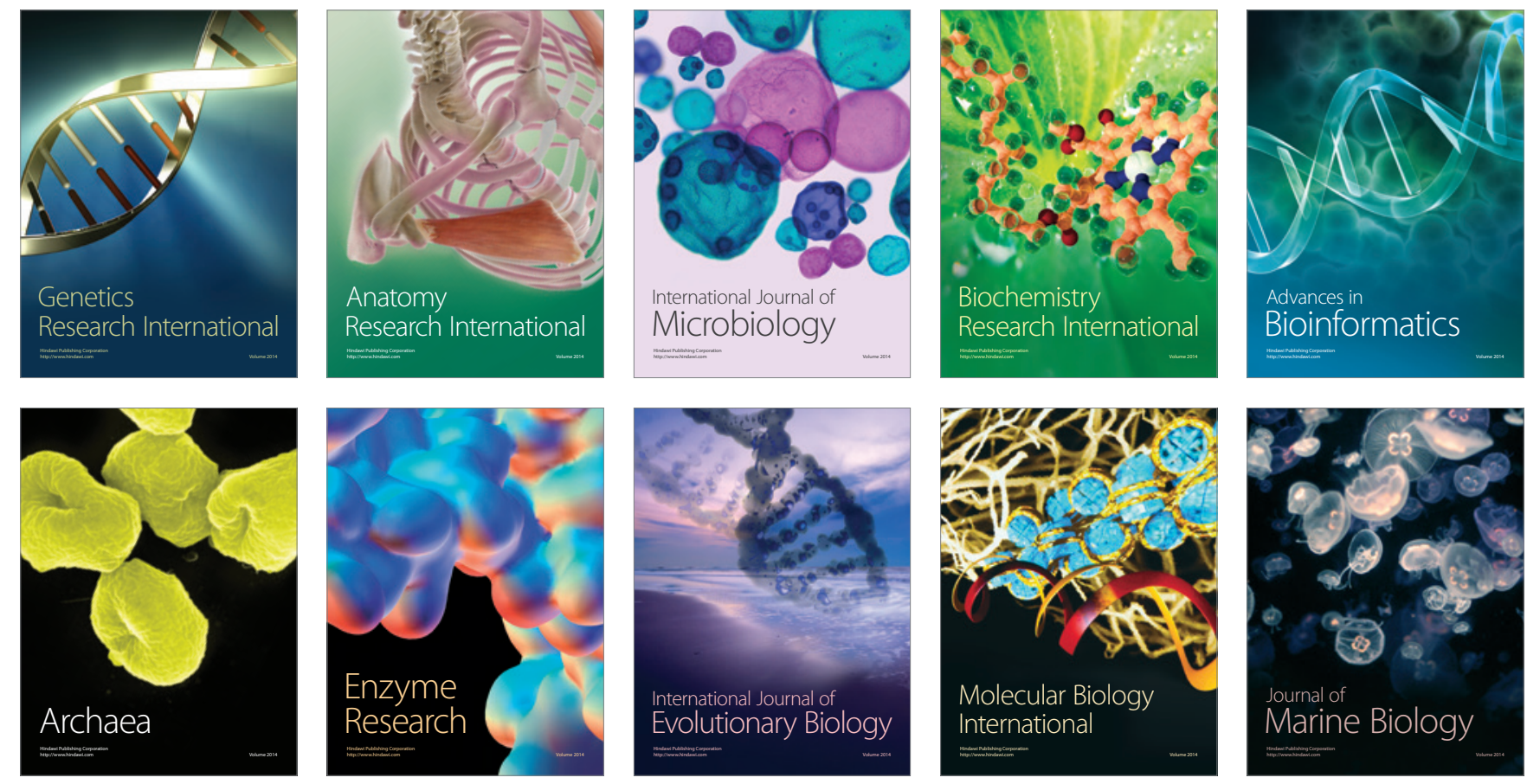